\title{
Letters from George Henry Lewes to Richard Hengist Horne
}

\section{G OR DON S. HA I GH T}

The University of Iowa Library has recently acquired for the Brewer-Leigh Hunt Collection twelve new autograph letters from George Henry Lewes to Richard Hengist Horne, which arc of particular interest because the two men came to know each other through Leigh Hunt. Horne had contributed to Leigh Hunt's Journal in 1835 and dedicated The Death of Marlowe to him in 1837. Lewes, just before he left for a year of study in Germany in 1838, received a copy of this book from Hunt with the inscription: "G. H. Lewes from his friend Leigh Hunt. (You must show this noble bit of tragedy to the German poets, \& get one of them to translate it.) "This volume is now in the Brewer Collection.

After Lewes returned to England, Hunt urged him to make Horne's acquaintance. Accordingly, on 10 March 1840 Lewes wrote:

I have been so long an admirer of your genius and energies so nobly directed towards the cultivation of a truer and higher feeling in our much abused Literature and have so long heard of you from our mutual friends Leigh Hunt, Egerton Webbe, Robert Bell, Williams etc. that I have naturally very much desired making your acquaintance, which I have expected to do at one of their houses; but fate having hitherto been adverse and being a thorough hater of conventionalities in themselves (only observing them in consideration of others) I feel satisfied that you are not the man to be captious at my present breaking through them and asking you if a call from me would be agreeable?

Horne was thirty-eight, fifteen years older than Lewes, but they found many common enthusiasms. At one of their early meetings Lewes apparently hinted that he would like to receive a copy of Gregory VII, the tragedy that Horne was just finishing, and Horne explained his objections to giving away copies of his books. In his next letter, 1 May 1840, Lewes protested that he had not been asking for a copy. "What I meant was that I was very anxious to see your new tragedy, (especially as I contemplate reviewing it in the Monthly Chronicle if space can be got.)" Lewes could not agree with Horne's objection to presenting copies, believing that if an unacted drama 
does not sell, it is better to give away copies, if one can afford to, than leave them "to the vile fate of Pastry." This suggestion is of particular interest because Horne acted upon it when in 1843 he offered his most famous book Orion for a farthing a copy.

A week later, having just finished reading Gregory VII, Lewes sent Horne an extravagant encomium, ranking it second only to Shelley's Cenci and some of Hunt's Legend of Florence. But in a postscript he confessed that in calling Horne's prefatory essay "a fit companion to Shelley's Defence of Poetry-which to me is the highest praise [that] can be bestowed," he had perhaps mixed a little self-love with its bravos, applauding his own notions. And when Lewes's review appeared in the Monthly Chronicle for July 1840 his critical estimate had somewhat cooled. He explained in his next letter to Horne that he was "dreadfully dissatisfied" with the review, but that he had at least quoted liberally from it,

and that I take it is doing you a service greater even than penetrating into the hidden recesses of character and construction-it will induce people to buy. But I am afraid that owing to the nonenthusiastic state of mind in which I sat down the whole affair will partake of it and consequently the praise appear colder than the blame.

The excuse Lewes offered for his "intellectual stupor" was the "vortex of visitings, dinings out, concerts, operas, etc." perhaps attendant on his wooing of Agnes Jervis, whom he married 18 February 1841. The day before the wedding Lewes wrote to Horne, agreeing to revise the proof of Gregory for the second edition; Horne must not suppose for an instant "that a wish of yours would not create leisure even in a treacle-moon! His letter contains a rapturous account of his bride, who, he said, shared his admiration of Horne's works; Lewes's first gift to her had been "a copy of Gregory-sent with my regards! and duly treasured." Nevertheless, he recognized that Horne's failure to see his plays produced on the stage was not entirely due to a conspiracy of the monopolistic managers, and he was sorry to see Horne allying himself with men like Heraud and Marston, who called themselves the Syncretics.

The energy of the Syncretics and their organ the "Monthly" remind me of spasmodic pug dogs fiercely denouncing the Mad Bull who careers through the street altogether heedless of poor Pug. I don't know whether I am libelling them, but from all I gather it does not seem the place for Gregory.

Another letter dated 12 July 1841 congratulated Horne on his being named a Sub-Commissioner on the Children's Employment Commission in Trade and Manufactures, a temporary appointment secured for him by his friend Dr. Southwood Smith. Several of Horne's articles are discussed in another letter, 4 January 1843. But relations be- 
tween the two men were growing more distant. Lewes was justly annoyed in 1844 when the rascally Thomas Powell spread the story that he had instigated Lewes to write in the Westminster the scathing review of Horne's New Spirit of the Age.

I trust that you never for an instant attributed the article to me. And Powell's statement (if he made it) is a deliberate lie. He never mentioned the subject. I have neither seen nor heard from him since the book has been out.

But his respect for truth, as I know of old, is of the slenderest.

The correspondence then seems to have lapsed for six years. In 1850 after Lewes and Thornton Hunt had founded the Leader Horne sent him a story called "The Coming Man," which Dickens, who employed him on Household Words, apparently would not publish. Lewes rejected it, though trying to soften the blow by reminding Horne that "some can't see anything in Thackeray, many did not read [Mrs. Gaskell's] Lizzie Leigh, Mrs. Crowe's story [then running serially in the Leader] cried up to the skies by some is thought rubbish by others." But though an editor's decision in cases of fiction is peculiarly delicate, especially when offered by friends, Lewes declares that "right or wrong I must stand by my own judgment." A second letter of this period, the only surviving part of a prolonged correspondence about another of Horne's articles, asks him to reduce it by at least half.

In 1852 Horne went to Australia, and there are no more letters from Lewes until 1866, when he was editing the Fortnightly Review. Horne was anxious to get some notice in English papers of his Prometheus, a lyrical drama written in a hut in the Australian mountains. He cited their mutual friend Mary Gillies as authority that Lewes had declined to admit a review of the poem. Lewes wrote 12 February 1866:

No review was ever proposed to me. No one has ever mentioned the poem to me by word or letter except Dr. Schmitz and Mary Gillies; and when Dr. Schmitz mentioned it to me he said you were very anxious about its reception. Therefore I told him as I told Mary Gillies that I could not notice it because I did not choose to give you pain and I could not write of it so as to give you pleasure. But in order that you might not suffer from my fastidiousness, I sent the poem to a distinguished contributor whom I knew to be a very warm admirer of 'Orion,' and asked him to write either an article or a critical notice. He sent me word that he tried to like it but couldn't, and excused himself from speaking of it. Since then I have thought it best to leave the poem alone and I still think so.

Lewes cordially assured Horne that his friends would be none the less delighted to welcome him back in England because the poem had made no stir. He would find them all greatly changed. His eldest son Charles Lee Lewes was married to Gertrude Hill, Dr. Southwood 
Smith's granddaughter, who had lived most of her life with Miss Gillies. Then, alluding to George Eliot, Lewes added: "As to my wife, whom you don't know in the flesh, she is a Mediaeval Saint with a grand genius."

In his reply Horne acquitted Lewes of "lèse friendship" in the Prometheus affair, and Lewes sent an acknowledgement with an account of his travels in the Lowlands and Germany during the summer of 1866, after the publication of Felix Holt. He enclosed a photograph of Charles and a long letter from Gertrude Lewes, which concludes this correspondence. Writing from Scotland, she soothed Horne's ego by assuring him that the Prometheus had impressed her deeply; "it has filled my mind with grand thoughts and brought before me beautiful cloud-pictures."

I only thought you would like to know the points that specially remain with me, dear Ganner. This is not the first time you have filled the small mite's mind with mysterious giant pictures, and made her see great forms stalking over far-spread plains and rising above woods-is it?

These excellent letters provide interesting new information about both Horne and Lewes and form a valuable addition to the Brewer Collection. 